Jurnal Kesehatan Reproduksi, 10(2), 2019:141-152

DOI: $10.22435 /$ kespro.v10i2.2412.141-152

\title{
PENINGKATAN KUNJUNGAN IBU HAMIL DI PUSKESMAS SEBAGAI EFEK DIGUNAKANNYA ULTRASOUND PADA PEMERIKSAAN KEHAMILAN
}

\section{Improvement of Pregnant Women Visit in Puskesmas as An Effect of Using Ultrasound in Pregnancy Examination}

\author{
Ingan Tarigan ${ }^{1 *}$, Tita Rosita ${ }^{2}$, Tin Afifah ${ }^{3}$, Soewarta Kosen ${ }^{4}$ \\ ${ }^{1}$ Pusat Penelitian dan Pengembangan Sumber Daya dan Pelayanan Kesehatan, Badan Litbangkes \\ ${ }^{2}$ Pusat Penelitian dan Pengembangan Humaniora dan Manajemen Kesehatan \\ ${ }^{3}$ Pusat Penelitian dan Pengembangan Upaya Kesehatan Masyarakat, Badan Litbangkes \\ ${ }^{4}$ Badan Penelitian dan Pengembangan Kesehatan \\ *Email: ingantr10@gmail.com
}

Naskah masuk 19 Desember 2019; review 19 Desember 2019; disetujui terbit 31 Desember 2019

\begin{abstract}
Background: Maternal and neonatal mortality rates are still a problem in Indonesia. Various efforts have been made, such as training and placing midwives in villages, increasing the number of deliveries performed in health facilities. There is a consensus that an important intervention is to provide appropriate health facilities managed by trained health workers who assist in childbirth, including midwives and doctors. One of the means of infrastructure that needs to be considered available at the community health center (puskesmas) is an ultrasound device to detect pregnancy complications.

Objective: The purpose of this study was to determine the effect of the use of ultrasound devices to increase antenatal care (ANC) to health centers.

Method: the study design was a quasi-experiment conducted at 20 puskesmas in Bogor district. Analyses was conducted in descriptive, the total sample participating in the study was 4,049 cases, but only 3,314 cases were analysed.

Result: The results of the study prove that the availability of USG at the puskesmas increases ANC visits to the puskesmas. The availability of ultrasound and the use of ultrasound affect the number of ANC visits to health facilities, especially to puskesmas. As an attraction for screening and ANC during pregnancy, the government needs to provide an ultrasound device at puskesmas.
\end{abstract}

Key words: Ultrasound, Antenatal Care, Puskesmas, Midwives, Pregnancy Complication

\begin{abstract}
Abstrak
Latar belakang: Angka kematian ibu dan neonatal masih merupakan masalah di Indonesia. Berbagai upaya telah dilakukan, seperti melatih dan menempatkan bidan di desa, meningkatkan jumlah persalinan yang dilakukan di fasilitas kesehatan. Ada konsensus yang menyatakan bahwa intervensi yang penting dilakukan adalah memberikan fasilitas kesehatan yang layak dikelola oleh tenaga kesehatan terlatih yang menolong persalinan, antara lain bidan dan dokter. Salah satu sarana prasarana yang perlu dipertimbangkan tersedia di puskesmas adalah alat ultrasound untuk mendeteksi komplikasi kehamilan.

Tujuan: mengetahui pengaruh penggunaan alat USG terhadap peningkatan antenatal care (ANC) ke puskesmas. Metode: disain penelitian adalah quasi eksperimen yang dilakukan pada 20 puskesmas di kabupaten Bogor. Analisis dilakukan secara deskriptif, total sampel yang berpatisipasi dalam penelitian 4.049 kasus, namun yang di analisis hanya 3.314 kasus.

Hasil: Ketersedian USG di puskesmas meningkatkan kunjungan ANC ke puskesmas.

Ketersediaan USG dan penggunaan USG mempengaruhi jumlah kunjungan ANC ke fasilitas kesehatan, khususnya ke puskesmas.

Sebagai daya Tarik untuk melakukan skrining dan ANC pada saat kehamilan, maka pemerintah perlu menyediakan alat USG di puskesmas.
\end{abstract}

Kata kunci: Ultrasound, Antenatal Care, Puskesmas, Bidan, Komplikasi Kehamilan 


\section{PENDAHULUAN}

Angka Kematian Ibu (AKI) di Indonesia sampai saat ini masih merupakan yang tertinggi dibandingkan dengan negara di Asia Tenggara lainnya. Berdasarkan hasil SDKI tahun 2007 Angka Kematian Ibu (AKI) sebesar 228 per 100,000 kelahiran hidup, dan pada tahun 2012 meningkat secara signifikan menjadi 359 per 100,000 kelahiran hidup. ${ }^{1,2}$ Hasil SUPAS menjelaskan AKI di Indonesia tahun 2015 sebesar 305 per 100.000 kelahiran hidup. ${ }^{3}$ Salah satu tujuan SDG's adalah menurunkan angka kematian ibu menjadi 102 per 100.000 kelahiran hidup. $^{4}$

Sebagian besar penyebab kematian ibu adalah akibat langsung dari komplikasi kehamilan, persalinan, dan post-partum antara lain perdarahan, persalinan macet, sepsis, preeklampsia, eklampsia, dan komplikasi akibat aborsi. Hasil SDKI tahun 2012 menjelaskan komplikasi yang berhubungan dengan kehamilan antara lain perdarahan 4 persen, persalinan prematur 2 persen, demam kejang 1 persen, dan komplikasi kehamilan lainnya $8 \%$. Sementara untuk komplikasi pada saat persalinan antara lain partus lama 35 persen, ketuban pecah dini 15 persen, demam 8 persen, perdarahan 8 persen, dan kejang 2 persen. ${ }^{1}$ Kematian ibu sangat terkait dengan kematian neonatal, dimana komplikasi kehamilan cenderung penyebab lahir mati dan kematian bayi. Pada umumnya kematian neonatal banyak terjadi pada saat persalinan dan segera setelah persalinan. Banyak hasil yang merugikan ini, dapat dicegah dengan memberikan pelayanan yang berkualitas selama kehamilan dan persalinan. Dalam pelayanan ANC sebaiknya juga memasukkan terkait promosi kesehatan, pencegahan, skrining dan diagnosis penyakit. ${ }^{5}$

Pemerintah Indonesia berkomitmen menurunkan Angka Kematian Ibu (AKI), hal ini dinyatakan dalam program pembangunan kesehatan dengan cara meningkatkan jumlah persalinan yang dilakukan di fasilitas kesehatan oleh tenaga

\footnotetext{
* Corresponding author

(Email: ingantr10@gmail.com )
}

(C) National Institute of Health Research and Development ISSN: 2354-8762 (electronic); ISSN: 2087-703X (print) kesehatan. Sejak tahun 1993, Kementerian Kesehatan mulai melatih 60,000 bidan dan menempatkan bidan di desa, khususnya pada daerah terpencil di Indonesia. Salah satu tujuan penempatan bidan desa tersebut adalah untuk meningkatkan mutu dan pemerataan pelayanan kesehatan khususnya di puskesmas.

Intervensi penting untuk mencegah kematian ibu dan neonatal adalah memberikan fasilitas perawatan kesehatan yang tepat dan baik kepada tenaga kesehatan yang terlatih, seperti bidan dan dokter. Ibu yang berisiko tinggi dan didiagnosis komplikasi, harus memiliki akses yang tepat terhadap fasilitas kesehatan yang menangani pelayanan emergensi kebidanan yang komprehensif.

Identifikasi faktor risiko dan komplikasi perlu dilakukan sedini mungkin agar ibu yang berisiko lebih cepat dan tepat penanganannya, sehingga perencanaan persalinan dapat dipersiapkan dengan baik khususnya di daerah sulit dan terpencil. Pemberian pelayanan ANC memperluas kesempatan untuk mengedukasi dan mengintervensi ibu atau keluarga untuk melahirkan di fasilitas kesehatan., World Health Organization (WHO) membuat pedoman yang di dalamnya mencakup rekomendasi terkait gizi, pemeriksaan ibu dan janin termasuk pengelolaan komplikasi kehamilan, tindakan pencegahan, intervensi untuk gejala fisiologis umum (mual, mulas, sembelit, dan lain lain) dan juga intervensi untuk meningkatkan pemanfaatan ANC dan kualitas pelayanan. Pedoman tersebut juga merekomendasikan minimal delapan kali kontak ibu hamil dengan petugas kesehatan. ${ }^{5}$

Deteksi dini komplikasi kehamilan dapat dilakukan dengan menggunakan Ultrasonography (USG), dimana alat tersebut mampu mendiagnosis berbagai kasus kehamilan dengan cepat dan akurat. Penggunaan USG pada sebagian besar negara maju merupakan bagian dari pelayanan antenatal kepada ibu hamil yang digunakan untuk skrining dan diagnosis. ${ }^{6}$ 
Penggunaan USG kebidanan pada negara maju menjadi salah satu pelayanan standar yang dipakai untuk mengidentifikasi anatomi dan patologi kehamilan, seperti posisi plasenta, posisi janin, kehamilan ektopik, jumlah kehamilan, dan kelangsungan hidup janin. Jika ada komplikasi yang teridentifikasi, maka dapat dilakukan penanganan yang lebih cepat dan terencana. ${ }^{7,8}$ WHO merekomendasikan pemeriksaan kehamilan menggunakan USG sebelum usia kehamilan 24 minggu untuk memastikan usia kehamilan yang akurat, mengidentifikasi kehamilan kembar, dan kondisi janin. Penilaian usia kehamilan dengan USG sangat penting untuk mengidentifikasi risiko kelahiran prematur serta memantau pertumbuhan janin yang optimal. ${ }^{9,5}$

Penelitian yang dilakukan di Bogor tentang penggunaan USG oleh bidan dan dokter sebagai supervisor di 20 puskesmas (10 puskesmas intervensi dan 10 puskesmas kontrol) untuk mengidentifikasi secara dini komplikasi selama kehamilan antara lain Intra Uterin Fetal Death (IUFD), kehamilan ganda, malpresentasi, dan plasenta previa. Bidan dan dokter dilatih menggunakan USG dalam pemeriksaan kehamilan. Ibu yang terdeteksi berisiko tinggi dirujuk ke fasilitas Pelayanan Obstetri Emergensi Komprehensif (PONEK). Rumah Sakit yang terlibat dalam penelitian ini adalah Rumah Sakit Umum Daerah (RSUD) Cibinong dan RSUD Ciawi, kabupaten Bogor. ${ }^{10,11}$

Hasil penelitian membuktikan bahwa bidan yang menggunakan alat USG mampu mendeteksi komplikasi kehamilan dengan baik dengan nilai sensitifitas dan spesifitas, preditive value $(+)$ dan predictive value (-) diatas 90 persen. Selain itu, bidan yang menggunakan alat USG untuk deteksi dini komplikasi kehamilan mempunyai kemampuan dua kali lebih tinggi dibandingkan dengan bidan yang tidak menggunakan alat USG. Bidan yang menggunakan USG dengan masa kerja < 12 tahun mempunyai kemampuan deteksi dini komplikasi kehamilan 6,38 kali lebih tinggi dibandingkan bidan tanpa alat USG dengan masa kerja $<12$ tahun. ${ }^{11}$

Hasil sistematic review menjelaskan bahwa pemanfaatan USG pada saat ANC sangat membantu untuk menilai usia kehamilan dan mendeteksi jika ada komplikasi kehamilan, sehingga manajemen persalinan lebih terencana dengan baik. ${ }^{12}$

Ketersediaan USG mendorong ibu hamil datang ke fasilitas kesehatan untuk pemeriksaan ANC, sehingga memungkinkan untuk deteksi dini dan peningkatan manajemen kebidanan. Deteksi dini dilakukan pada awal kehamilan atau akhir kehamilan atau kombinasi keduanya.

Kunjungan ANC pada ibu hamil memungkinkan kesempatan memberikan edukasi kepada ibu tentang persalinan yang aman. Selain itu, hubungan tenaga kesehatan yang terampil dengan ibu hamil selama kunjungan ANC dapat meningkatkan kemungkinan melahirkan pada tenaga kesehatan yang terlatih.

Terkait penggunaan alat USG dalam kebidanan, WHO melakukan sistematic review dan meta analisis untuk mengevaluasi keamanan penggunaan USG pada kehamilan. Hasil meta analisis yang melibatkan 25.000 perempuan menunjukkan bahwa USG selama kehamilan tidak meningkatkan risiko ibu masuk ke RS selama kehamilan. Demikian juga disampaikan bahwa paparan USG tidak meningkatkan secara signifikan risiko berat badan lahir rendah (BBLR). Hasil sistematic review tersebut menjelaskan bahwa penggunaan USG pada pemeriksaan kehamilan tampaknya tidak terkait dengan dampak yang merugikan terhadap maternal, perinatal, atau masa kanak-kanak, dan dianggap relatif aman untuk ibu dan janin. ${ }^{13}$ Tujuan dari analisis ini adalah untuk mengetahui pengaruh penggunaan USG terhadap peningkatan ANC di fasilitas kesehatan khususnya puskesmas.

\section{METODE}

Disain penelitian adalah quasi eksperimen. Studi dilakukan di Kabupaten Bogor, Jawa Barat. Dua puluh Puskesmas telah direkrut untuk studi ini dan dibagi menjadi kelompok intervensi (10 puskesmas) dan kelompok kontrol (10 puskesmas); yang cocok untuk beberapa karakteristik umum. Pemilihan puskesmas intervensi dan kontrol dilakukan dengan beberapa pertimbangan wilayah homogen, antara lain: letak puskesmas apakah urban atau rural, jumlah kehamilan selama satu tahun, jumlah bidan yang ada di puskesmas, jumlah bidan desa, jumlah kematian ibu selama satu tahun, jenis komplikasi kehamilan dan persalinan yang banyak ditemukan di puskesmas 
dan angka kemiskinan di wilayah tersebut. Rumah Sakit rujukan yang dipilih dalam penelitian ini adalah RSUD Cibinong dan RSUD Ciawi, kabupaten Bogor. ${ }^{10}$

Sampel dihitung berdasarkan perbandingan sensitivitas dalam mengidentifikasi komplikasi dari kehamilan ganda, malpresenstasi atau plasenta previa di antara ibu hamil dengan atau tanpa intervensi USG. Nilai P1 adalah sensitivitas perawatan standar tanpa USG, dan P2 adalah sensitivitas dengan USG. Diperkirakan prevalensi kasus dengan komplikasi sebesar 7 persen dan sekitar 50 persen kasus di identifikasi tanpa USG. Diharapkan 75 persen dari kasus akan di identifikasi dengan menggunakan USG. Untuk mendeteksi perbedaan sensitivitas, digunakan power dengan kekuatan 0,9 pada tingkat kepercayaan 0,05. Diprediksi 20 persen dari subjek akan drop out, sehingga sampel minimal yang diperlukan dalam studi ini untuk masingmasing kelompok intervensi dan kontrol sebanyak 1.375 ibu hamil (total $2.750 \mathrm{ibu}$ hamil). ${ }^{10}$

Sebelum penelitian, dilakukan pelatihan selama dua minggu penggunaan USG kepada 20 bidan dan 10 dokter yang terpilih yang berasal dari puskesmas intervensi. Kemudian bidan dan dokter tersebut melakukan praktek penggunaan alat USG selama dua bulan kepada ibu hamil yang datang ke puskesmas. Sementara untuk puskesmas kontrol hanya diberikan pelatihan tentang kuesioner dan metode penelitian. Materi yang dilatih khusus dibatasi hanya untuk mengidentifikasi kehamilan ganda, IUFD, malpresentasi dan plasenta previa. Setelah bidan dan dokter pelatihan dan praktek, baru di mulai pengumpulan data. ${ }^{10}$

Sampel ibu hamil diperiksa dua kali, yaitu pada puskesmas intervensi menggunakan USG dan puskesmas kontrol dilakukan secara manual. Pemeriksaan pertama pada periode 12-33 minggu masa kehamilan dan pemeriksaan kedua periode 34-40 minggu kehamilan. Jika pada pemeriksaan pertama terdeteksi kehamilan kembar atau IUFD, maka langsung dirujuk ke rumah sakit untuk mendapatkan penanganan lebih lanjut. Sementara jika pemeriksaan diidentifikasi malpresentasi atau plasenta previa, maka akan dilakukan pemeriksaan kedua pada usia kehamilan 34-40 minggu, dan jika tetap ditemukan komplikasi maka dirujuk ke rumah sakit. Prosedur pemeriksaan ANC tetap sesuai dengan standar Kementerian Kesehatan Republik Indonesia, perbedaannya hanya penggunaan USG di puskesmas intervensi. ${ }^{10}$

Proses manajemen dan analisis data dilakukan setelah data terkumpul. Variabel yang dianalisis antara lain ibu hamil yang datang untuk ANC, jumlah ibu hamil yang diperiksa dengan USG, jumlah ibu hamil yang diperiksa secara manual, usia ibu hamil, pendidikan ibu hamil, pendidikan suami, pekerjaan ibu hamil, pekerjaan suami, hasil pemeriksaan kehamilan, jenis komplikasi, penolong persalinan, tempat persalinan, metode persalinan, dan output persalinan (kondisi ibu dan bayi). Izin etik diperoleh dari Badan Litbangkes dengan nomor surat: KE.01.06/EC/416/2011 dan KE 01.08/EC/586/2012.

Keterbatasan studi ini adalah terkait validasi kasus di puskesmas dengan rumah sakit kasus yang dirujuk ke rumah sakit butuh waktu untuk melacak karena dokter kebidanan tidak lengkap mengisi formulir rujukan yang khusus dirancang dalam studi ini, sehingga harus dilacak sampai ke bagian rekam medik. Kemudian ada juga ibu hamil yang dirujuk dari puskesmas ke RSUD Cibinong atau RSUD Ciawi, tidak datang ke rumah sakit tersebut dengan alasan akses geografis. Ibu hamil tersebut cenderung lebih suka ke rumah sakit dekat dari rumah dan mudah diakses. Banyak juga kasus yang drop out dari penelitian karena ibu hamil tersebut tidak tinggal permanen di wilayah penelitian, sehingga pada saat menjelang melahirkan, pergi ke rumah orangtua dan melahirkan disana. Peneliti melakukan supervisi setiap bulannya selama penelitian untuk meminimalkan bias. ${ }^{10}$

\section{HASIL}

Total 4.049 kasus wanita hamil telah berpartisipasi dan terdaftar selama fase pendaftaran (Oktober 2011-April 2013). Ada 735 ibu hamil yang drop out karena tidak memenuhi kriteria etic clearance, sehingga kasus yang dianalisis sebanyak 3.314 ibu hamil. Sampel yang terpilih menandatangani formulir bahwa mereka bersedia berpartisipasi sukarela dalam penelitian ini. Ibu hamil yang diperiksa pada puskesmas kontrol sebanyak 1.706 kasus (51, 5\%) sementara di puskesmas intervensi 1.608 kasus (49\%). 


\section{Karakteristik Ibu Hamil}

Tabel 1 Karakteristik Ibu Hamil Berdasarkan Kelompok Puskesmas Daerah Penelitian di Kabupaten Bogor, Tahun 2011 s/d 2013

\begin{tabular}{|c|c|c|c|c|}
\hline \multirow{3}{*}{ Karakteristik } & \multicolumn{4}{|c|}{ Kelompok Puskesmas } \\
\hline & \multicolumn{2}{|c|}{ Kontrol } & \multicolumn{2}{|c|}{ Intervensi } \\
\hline & $\mathrm{n}$ & $\%$ & $\mathrm{n}$ & $\%$ \\
\hline \multicolumn{5}{|l|}{ Usia ibu (Tahun) } \\
\hline Tidak Berisiko (20-34) & 1.255 & 74,3 & 1.230 & 76,7 \\
\hline Risiko $(<20$ atau $35+)$ & 435 & 25,7 & 373 & 23,3 \\
\hline \multicolumn{5}{|l|}{ Pendidikan (Ibu Hamil) } \\
\hline Tinggi & 452 & 26,7 & 586 & 36,6 \\
\hline Rendah & 1.238 & 73,3 & 1.017 & 63,4 \\
\hline \multicolumn{5}{|l|}{ Pendidikan (suami) } \\
\hline Tinggi & 700 & 41,4 & 798 & 49,8 \\
\hline Rendah & 990 & 58,6 & 805 & 50,2 \\
\hline \multicolumn{5}{|l|}{ Pekerjaan (Ibu Hamil) } \\
\hline Tidak Bekerja & 1.533 & 90,7 & 1.239 & 77,3 \\
\hline Sekolah & 7 & 0,4 & 5 & 0,4 \\
\hline Karyawan & 44 & 2,6 & 76 & 4,7 \\
\hline Pengusaha & 35 & 2,1 & 59 & 3,7 \\
\hline Petani/Nelayan/Buruh & 50 & 3,0 & 59 & 3,7 \\
\hline Lain & 21 & 1,2 & 167 & 10,4 \\
\hline \multicolumn{5}{|l|}{ Pekerjaan (suami) } \\
\hline Tidak Bekerja & 37 & 2,2 & 16 & 1,0 \\
\hline Sekolah & 1 & 0,1 & 0 & 0,0 \\
\hline Karyawan & 120 & 7,1 & 237 & 14,8 \\
\hline Pengusaha & 593 & 35,1 & 677 & 42,1 \\
\hline Petani/Nelayan/Buruh & 891 & 52,7 & 611 & 38,1 \\
\hline Lain & 48 & 2,8 & 62 & 3,9 \\
\hline
\end{tabular}

Tabel satu menjelaskan sebagian besar usia ibu hamil yang tidak berisiko, dimana pada puskesmas kontrol sebesar 74 persen dan pada puskesmas intervensi 77 persen. Tidak ada perbedaan yang signifikan pada kedua kelompok terkait usia ibu hamil dengan $p$ value $=0,108$.

Pada puskesmas kontrol ibu hamil dengan pendidikan rendah (SMP atau dibawahnya) sebesar 73 persen lebih tinggi dibandingkan dengan ibu hamil pada puskesmas intervensi $(63 \%)$. Secara statistik ada perbedaan signifikan pada pendidikan ibu hamil ( $p$ value: $<0,001)$ pada kedua kelompok.

Berdasarkan tingkat pendidikan suami, pada puskesmas kontrol 59 persen dengan pendidikan rendah, sementara pada puksesmas intervensi hanya 50 persen. Ada perbedaan signifikan pada pendidikan suami dengan $p$ value $<0,001$ pada kedua kelompok.

Sebagian besar ibu hamil tidak bekerja pada kedua kelompok puskesmas, dimana pada puskesmas kontrol, ibu hamil yang tidak bekerja sebesar 91 persen lebih tinggi dibandingkan dengan puskesmas intervensi yaitu 77 persen. Secara statistik ada perbedaan yang signifikan status pekerjaan ibu hamil antara kedua kelompok dengan $\mathrm{p}$ value $<0,001$.

Persentase tertinggi pekerjaan suami pada puskesmas kontrol adalah petani/nelayan/buruh yaitu sebesar 53 persen, sementara pada puskesmas intervensi sebanyak 42 persen. Ada perbedaan signifikan pada pekerjaan suami dengan $p$ value $<0,001$ antara kedua kelompok. 
Tabel 2. Distribusi Frekuensi Status Komplikasi Kehamilan Berdasarkan Kelompok Puskesmas Daerah Penelitian di Kabupaten Bogor, Tahun 2011 s/d 20132015

\begin{tabular}{lrrrr}
\hline \multirow{2}{*}{ Jenis komplikasi } & \multicolumn{2}{c}{ Kontrol } & \multicolumn{2}{c}{ Intervensi } \\
\cline { 2 - 5 } Gemeli & 16 & 0,9 & 53 & 3,3 \\
Plasenta Previa & 4 & 0,2 & 13 & 0,8 \\
Mal Presentasi & 51 & 3,0 & 77 & 4,8 \\
IUFD & 1 & 0,1 & 2 & 0,1 \\
MP \& PP & 0 & 0,0 & 1 & 0,1 \\
Lain & 16 & 0,9 & 5 & 0,3 \\
Normal & 1.620 & 95,0 & 1.464 & 90,9 \\
\hline Total kasus & $\mathbf{1 . 7 0 6}$ & $\mathbf{1 0 0 , 0}$ & $\mathbf{1 . 6 0 8}$ & $\mathbf{1 0 0 , 0}$ \\
\hline
\end{tabular}

Catatan: $\mathrm{Mp}=$ Mal Presentasi; $\mathrm{PP}=\mathrm{Plasenta}$ previa; IUFD= lahir mati

Tabel 2 menjelaskan bahwa jumlah kasus gemeli (kehamilan kembar) di puskesmas intervensi sebesar 53 kasus (3\%) lebih tinggi dibandingkan dengan puskesmas kontrol 16 kasus $(0,8 \%)$. Kasus malpresentasi pada puskesmas intervensi yang diidentifikasi sebanyak 77 kasus (5\%), lebih tinggi dari pada puskesmas kontrol 51 kasus (3\%).

Jumlah komplikasi spesifik (gemeli, plasenta previa, malpresentasi dan IUFD) pada puskesmas yang menggunakan USG sebanyak 146 kasus (9\%), sementara pada puskesmas kontrol hanya 72 kasus (4\%). Total kasus komplikasi spesifik sebesar 218 kasus.

\section{Persalinan}

Tabel.3 Karakteristik Ibu Hamil Berdasarkan Komplikasi dan Kelompok Puskesmas Daerah Penelitian di Kabupaten Bogor, Tahun 2011 s/d 2013

\begin{tabular}{|c|c|c|c|c|c|c|c|c|c|}
\hline \multirow{3}{*}{ Persalinan } & \multicolumn{4}{|c|}{ Non komplikasi } & \multicolumn{4}{|c|}{ Complikasi } & \multirow{3}{*}{$\begin{array}{c}\mathrm{P} \\
\text { value }\end{array}$} \\
\hline & \multicolumn{2}{|c|}{ Kontrol } & \multicolumn{2}{|c|}{ Intervensi } & \multicolumn{2}{|c|}{ Kontrol } & \multicolumn{2}{|c|}{ Intervensi } & \\
\hline & $\mathrm{n}$ & $\%$ & $\mathrm{n}$ & $\%$ & $\mathrm{n}$ & $\%$ & $\mathrm{n}$ & $\%$ & \\
\hline \multicolumn{10}{|l|}{ Penolong Persalinan } \\
\hline Obgyn & 148 & 9,1 & 167 & 11,5 & 47 & 65,3 & 95 & 65,1 & 0,007 \\
\hline Dokter & 1 & 0,1 & 3 & 0,2 & 0 & 0,0 & 0 & 0,0 & $\mathrm{Na}$ \\
\hline Bidan & 1.000 & 61,8 & 896 & 61,5 & 21 & 29,2 & 34 & 23,3 & 0,046 \\
\hline Bidan desa & 385 & 23,8 & 321 & 22,0 & 3 & 4,2 & 10 & 6,8 & 0,048 \\
\hline Perawat & 2 & 0,1 & 2 & 0,1 & 0 & 0,0 & 0 & 0,0 & $\mathrm{Na}$ \\
\hline Paraji & 82 & 5,1 & 68 & 4,7 & 1 & 1,4 & 7 & 4,8 & 0,050 \\
\hline \multicolumn{10}{|l|}{ Tempat Persalinan } \\
\hline Rumah sakit & 163 & 10,1 & 229 & 15,7 & 48 & 66,7 & 107 & 73,3 & 0,028 \\
\hline Puskesmas & 122 & 7,5 & 268 & 18,4 & 2 & 2,8 & 7 & 4,8 & 0,727 \\
\hline Pondok bersalin & 13 & 0,8 & 96 & 6,6 & 0 & 0,0 & 3 & 2,1 & 1,000 \\
\hline Praktek Bidan & 1.180 & 72,9 & 766 & 52,6 & 15 & 20,8 & 22 & 15,1 & 0,021 \\
\hline Rumah & 140 & 8,7 & 98 & 6,7 & 7 & 9,7 & 7 & 4,8 & 0,710 \\
\hline \multicolumn{10}{|l|}{ Metode Persalinan } \\
\hline Normal & 1.533 & 94,7 & 1.359 & 93,3 & 38 & 52,8 & 82 & 56,2 & 0,000 \\
\hline Sectio Caesaria (SC) & 80 & 4,9 & 94 & 6,5 & 34 & 47,2 & 62 & 42,5 & 0,120 \\
\hline Alat bantu (vakum) & 5 & 0,3 & 4 & 0,3 & 0 & 0,0 & 2 & 1,4 & 0,455 \\
\hline
\end{tabular}

Tabel 3 menjelaskan pada kelompok kontrol, persalinan yang ditolong oleh dokter kebidanan dengan kasus komplikasi sebesar 65\% lebih tinggi dibandingkan dengan kasus nonkomplikasi (9\%). Ada perbedaan yang signifikan persalinan yang ditolong oleh dokter 
kebidanan pada kedua kelompok dengan $p$-value 0,007. Pada kelompok intervensi, persalinan yang ditolong oleh ibu hamil dengan kasus komplikasi sebesar 62 persen lebih tinggi dibandingkan dengan kasus non-komplikasi (23\%). Demikian juga pada kelompok kontrol, persalinan yang ditolong oleh bidan desa dengan kasus komplikasi sebesar 62 persen lebih tinggi dibandingkan dengan non-komplikasi (29\%). Ada perbedaan yang signifikan persalinan yang ditolong oleh bidan pada kedua kelompok dengan p-value 0,046. Hasil ini tidak jauh berbeda dengan persalinan yang ditolong oleh bidan desa, dimana ada perbedaan yang signifikan persalinan yang ditolong oleh bidan desa pada kedua kelompok dengan p-value 0,048 . Ibu yang melahirkan dengan paraji, secara statistik ada perbedaan yang signifikan antara kelompok komplikasi dibandingkan nonkomplikasi dengan $p$-value sebesar 0,050.

Berdasarkan tempat persalinan, pada kelompok intervensi, ibu yang melahirkan di rumah sakit dengan kasus komplikasi sebesar 73 persen lebih tinggi dibandingkan dengan ibu non-komplikasi (16\%). Demikian juga pada kelompok kontrol, ibu yang melahirkan di rumah sakit dengan komplikasi sebesar 67 persen lebih tinggi dibandingkan dengan non-komplikasi (10\%). Ada perbedaan yang signifikan untuk tempat persalinan pada kedua kelompok dengan $p$-value
0,028 .

Pada kelompok intervensi, ibu yang melahirkan pada praktek bidan dengan kasus komplikasi sebesar 15 persen lebih rendah dibandingkan dengan ibu non-komplikasi (53\%). Demikian juga pada kelompok kontrol, ibu yang melahirkan pada praktek bidan dengan komplikasi sebesar 21 persen, lebih rendah dibandingkan dengan ibu non-komplikasi $(10 \%)$. Ada perbedaan yang signifikan untuk persalinan yang dilakukan di praktek bidan pada kedua kelompok dengan $p$-value 0,021 . Untuk ibu yang melahirkan di puskesmas, polindes atau rumah secara statistik, tidak ada perbedaan yang signifikan di antara kedua kelompok.

Berdasarkan metode persalinan, pada kelompok intervensi, 15 persen ibu dengan komplikasi melahirkan dengan normal, lebih rendah dibandingkan ibu non-komplikasi (93\%). Demikian juga pada kelompok kontrol, ibu dengan komplikasi yang melahirkan normal sebesar 53 persen, lebih rendah dibandingkan dengan ibu non-komplikasi (95\%). Secara statistik, ada perbedaan pada metode persalinan antara kedua kelompok dengan $p$-value $<0,001$.

Ibu yang telah melahirkan dengan metode Saecaria (SC) atau vakum, secara statistik tidak ada perbedaan yang signifikan pada metode persalinan pada kedua kelompok dengan $p$-value 0,120 (SC) dan 0,455 (vakum). 


\section{Pelayanan Antenatal Care (ANC)}

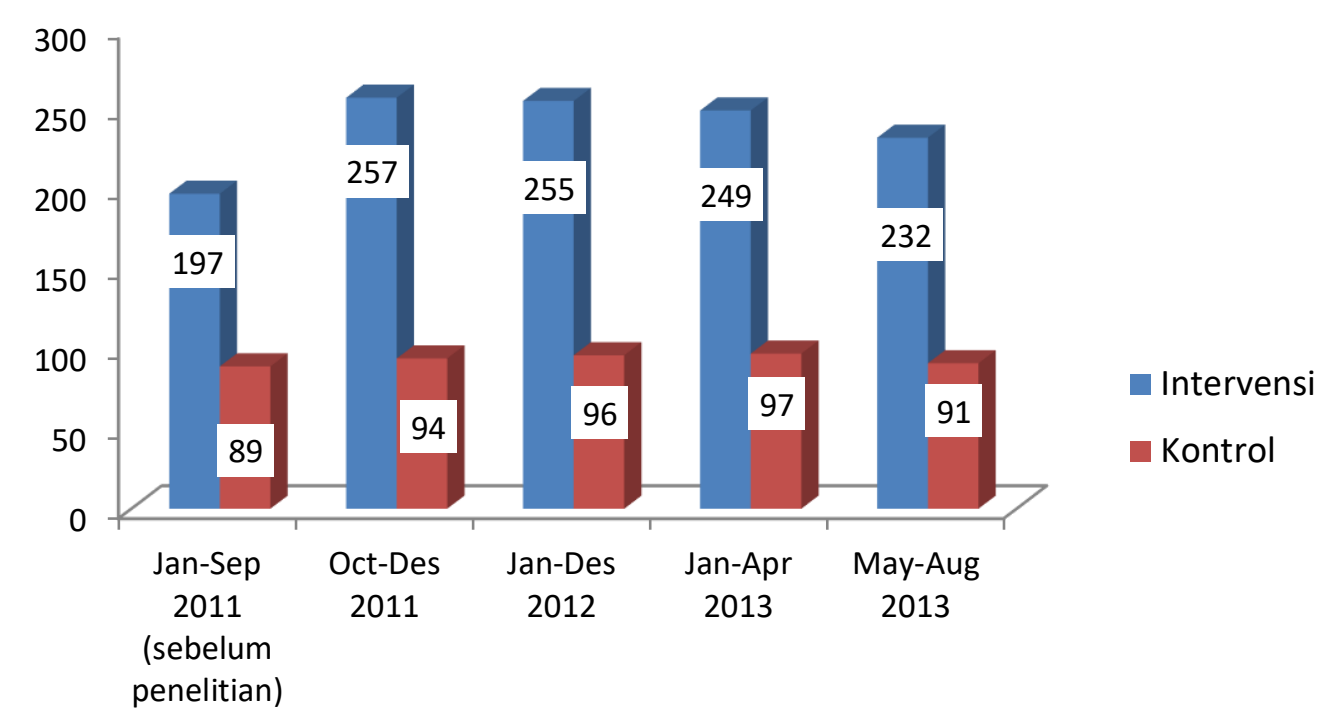

Gambar 1: Rata-rata Jumlah Kunjungan ANC per Bulan Berdasarkan

Kelompok Puskesmas Daerah Penelitian di Kabupaten Bogor, Tahun 2011 s/d 2013

Gambar satu menjelaskan trend rata-rata kunjungan ibu hamil untuk ANC per bulan di puskesmas, di mana pelayanan ANC diamati dari Januari 2011 s/d Agustus 2013. Khusus periode Januari s/d September 2011 adalah data kunjungan ibu hamil untuk ANC sebelum pengumpulan data, dan Oktober 2011 s/d Agustus 2013 adalah periode pengumpulan data. Khusus untuk Oktober 2011 s/d April 2013 adalah periode pendaftaran ibu hamil yang menjadi sampel.
Hasil analisis menunjukkan rata-rata kunjungan ANC per bulan pada puskesmas intervensi meningkat tajam pada periode penelitian (Oktober 2011 - April 2013) dibandingkan dengan puskesmas kontrol. Pada periode sebelum pengumpulan data, rata-rata jumlah kunjungan ANC pada puskesmas intervensi sebesar 197 kasus, kemudian meningkat tajam setelah pengumpulan data. Sementara pada puskesmas kontrol, jumlah kunjungan periode sebelum pengumpulan data dan setelah pengumpulan cenderung stagnan.

\section{Hubungan Penggunaan USG dengan Deteksi Dini Komplikasi Kehamilan}

Tabel 4: Hubungan Penggunaan USG dengan Deteksi Dini Komplikasi Kehamilan Daerah Penelitian di Kabupaten Bogor, Tahun 2011 s/d 2013

\begin{tabular}{lccccccc}
\hline \multirow{2}{*}{ Variabel } & \multicolumn{2}{c}{ Komplikasi } & \multicolumn{2}{c}{$\begin{array}{c}\text { Non } \\
\text { komplikasi }\end{array}$} & $\begin{array}{c}\text { p- } \\
\text { value }\end{array}$ & OR & CI 95\% \\
\cline { 2 - 5 } & $\mathbf{n}$ & $\mathbf{\%}$ & $\mathbf{n}$ & $\mathbf{\%}$ & & 1 & \\
\hline Pusk tanpa USG & 72 & 4,3 & 1618 & 95,7 & & 1 & \\
Pusk dengan USG & 146 & 9,1 & 1457 & 90,9 & 0,001 & 2,252 & $1,68-3,01$ \\
\hline
\end{tabular}


Puskesmas (bidan) yang menggunakan USG 2,25 kali lebih tinggi dibandingkan dengan puskesmas (bidan) yang tidak menggunakan USG dalam deteksi dini komplikasi kehamilan (gemelli, malpresentasi, plasenta previa, IUFD) dengan $\mathrm{p}$-value $<0,001$.

\section{PEMBAHASAN}

Berdasarkan karakteristik ibu hamil, pendidikan ibu hamil dan suami lebih baik pada puskesmas intervensi dibandingkan dengan puskesmas kontrol dan secara statistik ada perbedaan yang signifikan pada pendidikan ibu hamil dan suami. Demikian juga pekerjaan ibu hamil dan suami, secara statistik ada perbedaan yang signifikan antara kedua kelompok puskesmas, dimana pekerjaan ibu hamil dan suami lebih baik pada puskesmas intervensi dibandingkan dengan puskesmas kontrol. Kondisi ini menunjukkan bahwa ada pengaruh pendidikan dan pekerjaan dalam pelayanan kesehatan maternal.

Komplikasi kehamilan cenderung terdeteksi lebih banyak pada puskesmas yang menggunakan USG dalam deteksi dini komplikasi kehamilan dibandingkan puskesmas kontrol. Hasil penelitian menunjukkan bahwa kasus komplikasi dua kali lebih banyak terdeteksi pada puskesmas intervensi dibandingkan dengan puskesmas kontrol. Ada hubungan antara kasus komplikasi yang terdeteksi dengan puskesmas yang menggunakan USG (dalam hal ini pemeriksaan USG dilakukan oleh bidan) dibandingkan dengan puskesmas tanpa USG, dengan OR 2,25. Hal ini menjelaskan bahwa puskesmas dengan USG dalam pemeriksaan kehamilan memiliki probabilitas 2,25 kali lebih tinggi untuk mendeteksi komplikasi kehamilan dibandingkan dengan puskesmas yang tidak menggunakan USG. Hasil penelitian lain di daerah perdesaan di Uganda tentang penggunaan USG yang dibatasi hanya untuk skrining kehamilan yang berisiko. Hasil penelitian tersebut, menjelaskan bahwa dampak diagnostik dengan USG dapat mengidentifikasi kehamilan yang berisiko dari $7 \%$ menjadi $12 \%$ khususnya kehamilan kembar dan malpresentasi. ${ }^{14}$

Di Indonesia standar pelayanan ANC minimal 4 kali, namun dalam pemanfaatan pelayanan ANC belum terlalu memuaskan. Hasil Riskesdas 2018 menunjukkan ANC1 telah mencapai 96\%, namun kondisi ini berbeda dengan ANC 4 kali yang hanya mencapai $74 \% .{ }^{15}$

Faktor positif yang terkait dengan pemanfaatan pelayanan ANC 4 kali adalah pelayanan yang berkualitas dan status pendidikan ibu hamil yang tinggi. Sementara faktor yang menjadi kendala tidak memanfaatkan ANC 4 kali adalah faktor geografis, dan kehamilan yang tidak diinginkan. ${ }^{16}$ Hasil penelitian ini menunjukkan bahwa selama pengumpulan data, rata-rata kunjungan ANC per bulan pada puskesmas intervensi meningkat tajam dibandingkan dengan puskesmas kontrol. Hal ini menunjukkan bahwa ketersediaan alat USG di puskesmas tampaknya merupakan faktor yang menarik bagi ibu hamil yang ingin memeriksa lebih detail kondisi janin dalam rahim. Banyak ibu hamil sangat termotivasi untuk melakukan pemeriksaan USG. Daya Tarik USG pada ibu hamil karena konfirmasi visual awal kehamilan dan kontak dengan anak yang belum lahir. ${ }^{6}$ Pemeriksaan dengan USG merupakan peluang untuk mengenal bayi lebih baik dan memperdalam hubungan bayi dengan ibunya. ${ }^{17}$ Hasil penelitian Selemani Mbuyita et al, menjelaskan bahwa penggunaan USG pada klinik meningkatkan jumlah kunjungan ANC empat kali atau lebih dan memotivasi persalinan di fasilitas kesehatan. ${ }^{18}$ Demikian juga hasil penelitian Andrew B.Ross et al menunjukkan bahwa pengenalan USG dalam pelayanan ANC di Nawanyago HCII meningkatkan kunjungan ANC dan jumlah persalinan di fasilitas kesehatan. ${ }^{19}$ Penggunaan USG pada pemeriksaan kehamilan dapat digunakan juga untuk mempromosikan gaya hidup sehat selama kehamilan. ${ }^{17}$ Dampak lain adalah penggunaan USG cenderung meningkatkan persalinan di fasilitas kesehatan. Analisis multilevel di 28 negara Afrika tentang kualitas pelayanan ANC menunjukkan bahwa pelayanan antenatal yang berkualitas dapat meningkatkan cakupan persalinan dengan tenaga kesehatan. ${ }^{20}$ Pelayanan ANC yang berkualitas dapat mempengaruhi perilaku ibu cenderung memilih tenaga kesehatan sebagai penolong persalinan mereka dan membantu mereka dalam perencanaan persalinan yang lebih baik. ${ }^{21}$ Sebaliknya, buruknya kualitas pelayanan kesehatan ibu mengakibatkan ibu tidak mendapatkan pelayanan yang maksimal selama kehamilan dan persalinan. ${ }^{21}$ Dengan demikian, ketersediaan alat USG di Puskesmas dapat dipakai sebagai alat untuk meningkatkan kunjungan ANC. Selain itu, 
pelayanan ANC dengan menggunakan USG dapat mendeteksi dini komplikasi kehamilan, sehingga manajemen persalinan dapat dilakukan dengan terencana.

Hasil studi ini menjelaskan bahwa kompetensi bidan dalam memberikan pelayanan ANC dapat ditingkatkan dengan melatih bidan menggunakan alat USG untuk deteksi dini komplikasi kehamilan. Demikian juga hasil penelitian di Rwanda menjelaskan bahwa masalah akses ke fasilitas kesehatan yang tidak merata antara daerah perkotaan dan pedesaan dan juga antara berbagai kelompok sosial ekonomi disarankan selain dokter, bidan juga dilatih menggunakan USG dasar sebagai alat skrining. ${ }^{22}$ Namun penggunaan USG kebidanan perlu diseimbangkan indikasi medis dengan manfaat untuk mencegah penggunaan USG kebidanan yang berlebihan. ${ }^{22}$ Terkait antisipasi penggunaan USG yang berlebihan, perlu pedoman kebijakan dan praktek penggunaan USG yang tepat dalam kehamilan dan menggabungkannya dengan pelayanan ANC. ${ }^{23}$

Terkait pelayanan ANC, WHO merekomendasikan penggunaan alat USG sebelum kehamilan 24 minggu untuk memperkirakan usia kehamilan, meningkatkan deteksi dini komplikasi. WHO tidak merekomendasikan penggunaan USG setelah 24 minggu kehamilan kecuali pertimbangan belum pernah dilakukan pemeriksaan dengan USG sebelum umur 24 minggu kehamilan, untuk mengidentifikasi kehamilan ganda, presentasi janin dan letak plasenta. Salah satu manfaat dari pemeriksaan dengan USG adalah peningkatan akurasi dan ketepatan usia kehamilan, sehingga manajemen persalinan dapat terencana dengan baik dan ancaman kelahiran prematur dapat dihindari. Selain itu, pengenalan USG dalam mendeteksi komplikasi dapat meningkatkan pelayanan ANC dan mengurangi angka kesakitan dan kematian. ${ }^{9}$ Rekomendasi WHO tentang penggunaan USG, harus didukung sistem kesehatan (logistik, infrastruktur, kemampuan tenaga kesehatan) untuk penyediaan layanan, rujukan dan pengelolaan komplikasi yang teridentifikasi. $^{5}$

\section{KESIMPULAN}

Pendidikan dan pekerjaan punya peran penting dalam pelayanan kesehatan maternal. Deteksi dini komplikasi kehamilan dua kali lebih banyak terdeteksi pada puskesmas dengan USG dibandingkan dengan puskesmas tanpa USG.

Selama penelitian, terjadi peningkatan yang tajam rata-rata kunjungan ANC per bulan pada puskesmas dengan USG dibandingkan dengan puskesmas tanpa USG. Beberapa hasil penelitian lain juga membuktikan bahwa penggunaan USG untuk deteksi dini komplikasi kehamilan dan memberikan informasi terkait kondisi janin kepada ibu dan keluarganya, dapat meningkatkan pemanfaatan ANC pada ibu hamil.

Terkait keterbatasan tenaga kesehatan khususnya di daerah sulit, selain dokter dapat juga dilatih bidan dalam menggunakan USG yang hanya dibatasi untuk skrining komplikasi kehamilan. Namun dipastikan harus ada pengawasan dalam penggunaan USG.

\section{SARAN}

Penggunaan USG untuk pemeriksaan kehamilan dapat diintegrasikan dalam pelayanan ANC di fasilitas kesehatan. Sesuai dengan saran WHO, pemeriksaan kehamilan dilakukan sebelum usia kehamilan 24 minggu, untuk mengetahui usia kehamilan dengan tepat dan mendeteksi komplikasi kehamilan secara dini.

Pemerintah perlu menyediakan perangkat USG di fasilitas kesehatan khususnya di puskesmas untuk skrining komplikasi kehamilan dan juga sebagai bagian dari peningkatan kualitas pelayanan kebidanan. Diharapkan dengan ketersediaan alat USG di puskesmas, dapat meningkatkan pelayanan ANC kepada ibu hamil.

Ketersediaan alat USG juga di prioritaskan pada daerah sulit, dengan melatih dokter dan bidan menggunakan alat USG. Hal ini diharapkan dapat berkontribusi untuk meningkatkan kualitas pelayananan kebidanan dan manajemen persalinan lebih terencana dengan baik.

Upaya ini dapat dikombinasikan dengan pengembangan tele-medicine yang menghubungkan dokter atau bidan di daerah sulit dengan dokter kandungan di fasilitas rujukan.

\section{UCAPAN TERIMA KASIH}


Kami mengucapkan terimakasih kepada Kepala Badan Litbangkes yang sudah mendukung penelitian ini, khususnya kepada dr. Soewarta Kosen, MPH, Dr.PH selaku Ketua Pelaksana, dan tim peneliti Badan Litbangkes yang terlibat serta kerjasama yang baik dengan Dinas kesehatan Kabupaten Bogor, tim puskesmas, dan juga tim RSUD Cibinong dan RSUD Ciawi. Ucapan terimakasih juga kami sampaikan kepada GE Pacific PTE LTD dan GE Indonesia yang memberikan hibah dan dukungan teknis dalam studi ini.

\section{DAFTAR PUSTAKA}

1. Statistics Indonesia (Badan Pusat Statistik [BPS]), National Population and Family Planning Board (BKKBN), Indonesia Ministry of Health (Depkes RI), ICF International. Indonesia Demographic and Health Survey 2012. ... Heal Care [Internet]. 2013; Available from: http://www.dhsprogram.com

2. Statistics Indonesia, Ministry of Health of the Republic of Indonesia, Macro International. Indonesia Demographic and Health Survey 2007. 2008;1-515.

3. United Nations Population Fund (UNFPA) Indonesia. Ninth Country Programme 2016-2020 Annual Report 2016. 2016;

4. Kemenkes RI. Kesehatan Dalam Kerangka Sustainable Development Goals (SDGs). 2015;(97):85.

5. Tunçalp, Pena-Rosas JP, Lawrie T, Bucagu M, Oladapo OT, Portela A, et al. WHO recommendations on antenatal care for a positive pregnancy experiencegoing beyond survival. BJOG An Int J Obstet Gynaecol [Internet]. 2017;124(6):860-2. Available from: https://doi.org/10.1111/1471-0528.14599

6. Garcia J, Bricker L, Henderson J, Martin M-A, Mugford M, Nielson J, et al. Women's Views of Pregnancy Ultrasound: A Systematic Review. Birth [Internet]. 2002 Dec 1;29(4):225-50. Available from: https://doi.org/10.1046/j.1523536X.2002.00198.x

7. Shah SP, Epino H, Bukhman G, Umulisa I, Dushimiyimana JM V, Reichman A, et al. Impact of the introduction of ultrasound services in a limited resource setting: rural
Rwanda 2008. BMC Int Health Hum Rights [Internet]. 2009;9:4. Available from: http://www.ncbi.nlm.nih.gov/pubmed/193 27157\%5Cnhttp://www.pubmedcentral.nih .gov/articlerender.fcgi?artid=PMC2667437

8. Kimberly HH, Murray A, Mennicke M, Liteplo A, Lew J, Bohan JS, et al. Focused maternal ultrasound by midwives in rural zambia. Ultrasound Med Biol. 2010;36(8):1267-72.

9. WHO. Experience : Ultrasound Examination Highlights and Key Messages from the World Health Organization's 2016 Global Recommendations. 2018;1(January):2013-6. Available from: https://apps.who.int/iris/bitstream/handle/1 0665/259946/WHO-RHR-18.01eng.pdf? sequence $=1$

10. Center for Community Empowerment Health Policy and Humanities, NIHRD Ministry of Health I 2013. Study on Physician and Midwife Screening Ultrasound for Pregnancy Complications in Bogor District, West Java, Indonesia. 2013.

11. Tarigan IU. Potensi pencegahan kesakitan dan kematian perinatal melalui pemeriksaan oleh bidan dengan menggunakan ultrasound di Kabupaten Bogor tahun 2011-2013.

12. Whitworth M, Bricker L, Neilson JP, Dowswell T. Ultrasound for fetal assessment in early pregnancy. Cochrane database Syst Rev [Internet]. 2010 Apr 14;(4):CD007058-CD007058. Available from:

https://www.ncbi.nlm.nih.gov/pubmed/203 93955

13. Torloni MR, Vedmedovska N, Merialdi M, Betrán AP, Allen T, González R, et al. Safety of ultrasonography in pregnancy: WHO systematic review of the literature and meta-analysis. Ultrasound Obstet Gynecol. 2009;33(5):599-608.

14. Swanson JO, Kawooya MG, Swanson DL, Hippe DS, Dungu-Matovu P, Nathan R. The diagnostic impact of limited, screening obstetric ultrasound when performed by midwives in rural Uganda. $\mathrm{J}$ Perinatol [Internet]. 2014;34(7):508-12. Available from: 
https://doi.org/10.1038/jp.2014.54

15. National Institute Health Research and Development I. Basic Health Research Report of Indonesia Year 2018 (Laporan Nasional Riskesdas 2018). Riskesdas 2018. 2018. p. 182-3.

16. Gupta S, Yamada G, Mpembeni R, Frumence G, Callaghan-Koru JA, Stevenson R, et al. Factors Associated with Four or More Antenatal Care Visits and Its Decline among Pregnant Women in Tanzania between 1999 and 2010. PLoS One [Internet]. 2014 Jul 18;9(7):e101893. Available from: https://doi.org/10.1371/journal.pone.01018 93

17. Molander E, Alehagen S, Berterö CM. Routine ultrasound examination during pregnancy: a world of possibilities. Midwifery [Internet]. $2010 \mathrm{Feb}$ 1;26(1):18-26. Available from: https://doi.org/10.1016/j.midw.2008.04.00 8

18. Mbuyita S, Tillya R, Godfrey R, Kinyonge I, Shaban J, Mbaruku G. Effects of introducing routinely ultrasound scanning during Ante Natal Care (ANC) clinics on number of visits of ANC and facility delivery: a cohort study. Arch Public Health [Internet]. 2015 Sep 7;73(1):36. Available from: https://www.ncbi.nlm.nih.gov/pubmed/263 47809

19. Ross AB, DeStigter KK, Rielly M, Souza S, Morey GE, Nelson M, et al. A low-cost ultrasound program leads to increased antenatal clinic visits and attended deliveries at a health care clinic in rural uganda. PLoS One [Internet]. 2013;8(10). Available from: https://doi.org/10.1371/journal.pone.00784 50

20. Chukwuma A, Wosu AC, Mbachu C, Weze K. Quality of antenatal care predicts retention in skilled birth attendance: a multilevel analysis of 28 African countries. BMC Pregnancy Childbirth [Internet]. 2017;17(1):152. Available from: https://doi.org/10.1186/s12884-017-1337-1

21. Afulani PA, Buback L, Essandoh F, Kinyua J, Kirumbi L, Cohen CR. Quality of antenatal care and associated factors in a rural county in Kenya: an assessment of service provision and experience dimensions. BMC Health Serv Res [Internet]. 2019;19(1):684. Available from: https://doi.org/10.1186/s12913-019-4476-4

22. Holmlund S, Ntaganira J, Edvardsson K, Lan PT, Semasaka Sengoma JP, Åhman A, et al. Improved maternity care if midwives learn to perform ultrasound: a qualitative study of Rwandan midwives' experiences and views of obstetric ultrasound. Glob Health Action [Internet]. 2017;10(1):1350451. Available from: https://www.ncbi.nlm.nih.gov/pubmed/287 64602

23. Gammeltoft T, Nguyên HTT. The Commodification of Obstetric Ultrasound Scanning in Hanoi, Viet Nam. Reprod Health Matters [Internet]. 2007 Jan 1;15(29):163-71. Available from: https://doi.org/10.1016/S09688080(06)29280-2 